\title{
IBA and Rooting Media Influenced Survival, Rooting and Vegetative Growth in Air Layering of Guava (Psidium guajava L.) cv. L-49
}

\author{
Ajay Punasya*, Jyoti Kanwar and Rajiv Dubey
}

Department of Fruit science, K.N.K. college of Horticulture, RVSKVV, Gwalior, India

*Corresponding author

\section{A B S T R A C T}

Keywords

Guava, Air layering, IBA, Rooting media and polythene

Article Info

Accepted:

10 July 2018

Available Online:

10 August 2018
An investigation on "effect of IBA, rooting media and polythene wrappers on air layering on guava cv. L-49" was undertaken at the Department of Fruit Science, KNK College of Horticulture, Mandsaur, RVSKVV, Gwalior (M.P.) during the year of 2015-16. The experiment was laid out in Randomized Block Design (RBD) with three replications. There were different concentration of IBA (2000 ppm, $4000 \mathrm{ppm}$ and 6,000 ppm), rooting media (sphagnum moss and cocopeat) and different polythene wrappers (Black and White polythene) used as an air layering preparation in Guava. The results that maximum rooting $(85.33 \%)$, number of primary (12.87) and secondary roots (33.33), length of primary $(28.67 \mathrm{~cm})$ and secondary roots $(5.10 \mathrm{~cm})$, diameter of primary roots $(6.40 \mathrm{~mm})$, fresh $(4.20 \mathrm{~g})$ and dry weight $(0.90 \mathrm{~g})$ of roots in layers prepared by application of IBA@6000 rolled in sphagnum moss and covered by Black Polythene. Growth of these layers was vigorous as depicted by new sprouts (9.67), number of leaves (47.00) and branches (8.00) per layered at 90 days after separation from mother plant. This was followed by layers treated with IBA@6000ppm + Sphagnum moss + White Polythene.

\section{Introduction}

The guava is one of the most common and important fruit crop cultivated all over India. It is fourth most important fruit crop in area and production after mango, banana and citrus. Much of the interest in common guava has been due to its delightful taste and flavour (Pedapati and Tiwari, 2014). Guava is propagated by seeds and vegetative methods. Seed propagated plants start bearing fruits in 3-4 years, while that of from vegetative method (air layering) starts bearing in 2-3 years of age. To maintain true-to-type cultivar, it is necessary to go through the vegetative method of propagation for guava. Air layering is the oldest method of vegetative propagation. For rooting, auxins particularly IBA, have been reported to induce rooting in many of the plant species with varied success (Bhagat, 1998). Local farmers used soil and compost as a rooting media and wrap with gunny bags. It is found that certain percentage of layers die in the nursery due to regular water evaporation and low water holding capacity of rooting media creates moisture crisis (Singh, 2007). Moisture is the important factor for rooting success because of presence of sufficient soil moisture, humidity and optimum temperature which are prerequisites of maximum survival 
of the detached air- layers. The moisture level can be enhanced by a suitable rooting media with sufficient porosity, water holding capacity and microbial activity can increase the chances of newly formed roots of a stem for their easy penetration and healthy growth of air-layering. Wrapping material also plays an important role in success of air layering by high permeability to gases like oxygen and carbon dioxide, and a very low permeability to water vapour. Keeping the above facts in view, an experiment is planned to find out suitable IBA concentration, appropriate media and covering material for higher success.

\section{Materials and Methods}

The experiment was carried out studies on effect of IBA, rooting media and wrapping material on survival and rooting of air layering of guava cv. L-49 during the period of 201516 , at the department of fruit science, K.N.K college of Horticulture, Mandsaur, RVSKVV, Gwalior. The experiment was laid out in Randomized Block design with three levels of IBA (2000 ppm, 4000 ppm and 6,000 ppm), rooting media (sphagnum moss and cocopeat) and different polythene wrappers (Black and White polythene) along with control (untreated) used as an air layering preparation in Guava. Thus 13 treatments were replicated three times. Thirty layers prepared each treatment formed a unit.

\section{Selection of plants and shoots for air layering}

For the experiment, 13 years old plant of Guava of uniform vigour and size were selected and about 4 - 6 month old healthy branches of pencil thickness were selected for air-layering. On the selected trees one year old shoots of pencil size thickness were selected randomly for air layering. The lengths of branches were $45-60 \mathrm{~cm}$ with high sap flow showing smooth bark.

\section{Method of Application}

After selection of branches, a ring of bark about $2 \mathrm{~cm}$ wide was removed carefully from the selected shoot of guava just below the bud without injuring to the underlying wood, it was done just below the node by giving two circular cuts about $45-60 \mathrm{~cm}$ below the top end of a shoots. Previously prepared solution containing IBA as per treatment were applied evenly on all sides of the upper cut of the ring. The applied cut portion was covered with rooting media cocopeat or sphagnum moss and white or black polythene wrappers according to treatment combinations. Control shoot were left as such. The polythene sleeve was of $15 \times 20 \mathrm{~cm}$ in size, 150 gauges of thickness. The distal end of the sleeve was tied on the stem at a distance of $5-6 \mathrm{~cm}$ below the ring with the help of gunny thread. The rooting media i.e. sphagnum moss or cocopeat were firmly filled into the sleeve and the upper end was also sealed with gunny thread to minimize the evaporation of moisture.

\section{Detachment rooted air layers}

After 60 days for the date of operation airlayers were detached by given three installations cut at an interval of one week, so as to reduce the shock of sudden detachment. The first ' $\mathrm{V}$ ' shaped cut given $1 / 3$ th of the total diameter of the layered shoot, the second cut given to further deepen the first cut to about half of the shoot thickness and the final cut was given at the time of transplanting.

The air layers were brought under shade after detachment and their polythene covers were removed gently. Care was taken to ensure that the roots were not injured at the time of removing polythene wrappers. After this rooted air layers were planted in polythene bags. The data was statistical analysed by following procedure as suggested by Panse and Sukhatme (1989). 


\section{Results and Discussion}

The data depicted in table 1 revealed that different concentrations of IBA and rooting media with black polythene significantly increased success in rooting percent of airlayers over the control. The layers prepared by using IBA@6,000 ppm + Sphagnum moss + Black polythene was superior all over treatment for producing maximum rooting $(85.33 \%)$, callus formation $(5.67 \mathrm{~mm})$, number of primary (28.67) and secondary roots $(33.33)$, length of primary $(12.87 \mathrm{~cm})$ and secondary roots $(5.10 \mathrm{~cm})$, diameter of primary roots $(6.40 \mathrm{~mm})$, fresh $(4.20 \mathrm{~g})$ and dry weight $(0.90 \mathrm{~g})$ of roots. This was followed by layers treated with IBA 6,000 ppm + Sphagnum moss + White polythene. It was appeared to be an increasing tendency of rooting with an increasing concentration, this might be at higher concentration of IBA the quantity of auxin reaching the cambial activity may be adequate for initiating root primordia, so the highest performance was seen at higher concentrations of IBA indicating the possibility of better success with employing higher concentrations of IBA (Bhagat et al., 1999). The sphagnum moss had more success perhaps due to its capacity to retain higher moisture retention with high porosity for better aeration. Cocopeat did not work effectively due to low water holding capacity. Among the polythenes, using of black polythene enhanced rooting success as compared to white polythene, this may be due to screening of the sun-rays from passing inside and thereby creating the optimum condition for root development by conserving moisture inside the air layer in black polythene. Hence the combination of these three made possible overall rooting success at higher. These results are in accordance with the findings of Singh and Jawanda (1981) in litchi, Patel et al., (1996) in guava, Maurya et al., (2012) in guava and Rambai and Sathyanarayana, (2010) in guava.

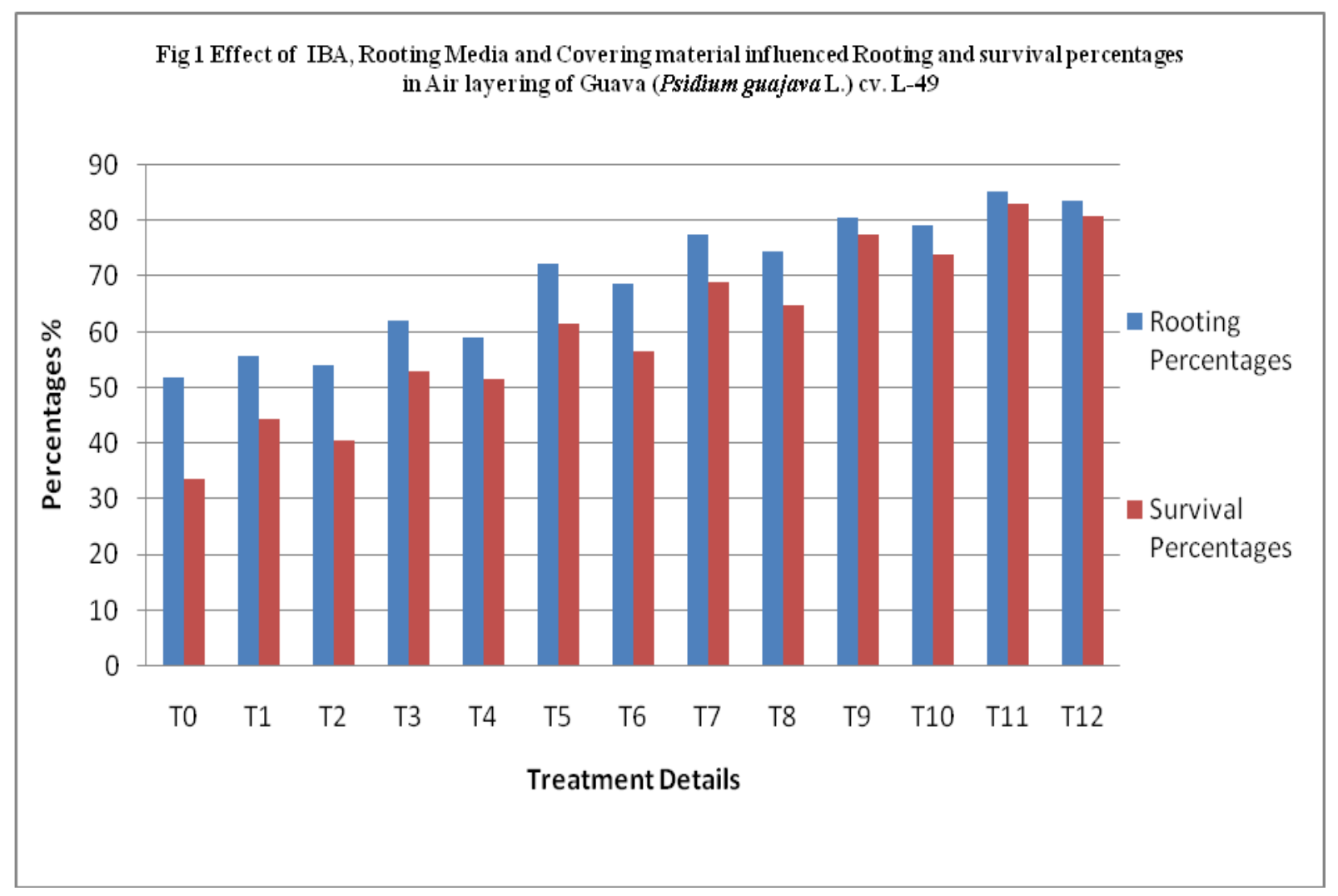


Table.1 Effect of IBA, rooting media and covering material influenced survival, rooting and vegetative growth in air layering of guava (Psidium guajava L.) cv. L-49

\begin{tabular}{|c|c|c|c|c|c|c|c|c|c|c|c|c|}
\hline $\begin{array}{l}\text { Treatments } \\
\text { Details }\end{array}$ & $\begin{array}{l}\text { Rooting } \\
\%\end{array}$ & $\begin{array}{c}\text { Callus } \\
\text { formation } \\
(\mathbf{m m})\end{array}$ & $\begin{array}{l}\text { Number } \\
\text { of } \\
\text { primary } \\
\text { shoots }\end{array}$ & $\begin{array}{l}\text { Number of } \\
\text { secondary } \\
\text { shoots }\end{array}$ & $\begin{array}{l}\text { Length of } \\
\text { primary } \\
\text { roots } \\
\text { (cm) }\end{array}$ & $\begin{array}{l}\text { Length of } \\
\text { secondary } \\
\text { roots } \\
\text { (cm) }\end{array}$ & \begin{tabular}{|} 
Diameter \\
of \\
primary \\
roots \\
$(\mathrm{mm})$
\end{tabular} & $\begin{array}{l}\text { Fresh } \\
\text { weight } \\
\text { of root } \\
\text { (g) }\end{array}$ & $\begin{array}{c}\text { Dry } \\
\text { weight } \\
\text { of roots } \\
\text { (g) }\end{array}$ & $\begin{array}{c}\text { Number } \\
\text { of new } \\
\text { sprouts }\end{array}$ & $\begin{array}{l}\text { Number } \\
\text { of leaves }\end{array}$ & $\begin{array}{c}\text { Survival } \\
\%\end{array}$ \\
\hline Control & 52.00 & 1.93 & 10.00 & 13.33 & 5.47 & 1.20 & 2.57 & 1.33 & 0.27 & 3.00 & 21.33 & 33.67 \\
\hline $\begin{array}{l}\text { IBA@2,000 ppm + Cocopeat + } \\
\text { Black polythene }\end{array}$ & 55.67 & 3.20 & 17.00 & 22.00 & 7.30 & 1.90 & 3.13 & 1.77 & 0.35 & 3.67 & 25.67 & 44.33 \\
\hline $\begin{array}{l}\text { IBA@2,000 ppm + Sphagnum } \\
\text { moss + Black polythene }\end{array}$ & 62.00 & 3.70 & 21.33 & 23.67 & 8.03 & 2.80 & 3.70 & 2.13 & 0.50 & 5.00 & 29.00 & 53.00 \\
\hline $\begin{array}{l}\text { IBA@2,000 ppm + Sphagnum } \\
\text { moss + White polythene }\end{array}$ & 59.00 & 3.47 & 18.67 & 22.67 & 7.60 & 2.57 & 3.40 & 1.93 & 0.43 & 4.67 & 26.67 & 51.67 \\
\hline $\begin{array}{l}\text { IBA@4,000 ppm + Cocopeat + } \\
\text { Black polythene }\end{array}$ & 72.33 & 4.27 & 23.00 & 26.33 & 8.97 & 3.57 & 4.50 & 2.67 & 0.62 & 5.67 & 33.00 & 61.67 \\
\hline $\begin{array}{l}\text { IBA@4,000 ppm + Sphagnum } \\
\text { moss + Black polythene }\end{array}$ & 77.67 & 4.73 & 23.00 & 28.33 & 9.70 & 4.13 & 4.93 & 3.23 & 0.70 & 6.67 & 37.00 & 69.00 \\
\hline $\begin{array}{l}\text { IBA@4,000 ppm + Sphagnum } \\
\text { moss + White polythene }\end{array}$ & 74.67 & 4.60 & 22.67 & 27.67 & 9.13 & 3.90 & 4.77 & 2.93 & 0.68 & 6.33 & 35.33 & 65.00 \\
\hline $\begin{array}{l}\text { IBA@6,000 ppm +Cocopeat + } \\
\text { Black polythene }\end{array}$ & 80.67 & 5.17 & 26.67 & 31.33 & 11.20 & 4.60 & 5.70 & 3.77 & 0.80 & 8.00 & 42.00 & 77.67 \\
\hline $\begin{array}{l}\text { IBA@6,000 ppm + Cocopeat+ } \\
\text { White polythene }\end{array}$ & 79.33 & 4.87 & 26.00 & 30.33 & 10.40 & 4.30 & 5.17 & 3.57 & 0.76 & 7.67 & 40.00 & 74.00 \\
\hline $\begin{array}{l}\text { IBA@6,000 ppm + Sphagnum } \\
\text { moss +Black polythene }\end{array}$ & 85.33 & 5.67 & 28.67 & 33.33 & 12.87 & 5.10 & 6.40 & 4.20 & 0.90 & 9.67 & 47.00 & 83.00 \\
\hline $\begin{array}{l}\text { IBA@6,000 ppm + Sphagnum } \\
\text { moss + White polythene }\end{array}$ & 83.67 & 5.53 & 27.00 & 32.33 & 11.97 & 4.87 & 5.97 & 3.93 & 0.83 & 8.67 & 44.00 & 81.00 \\
\hline Sem \pm & 2.06 & 0.46 & 1.93 & 1.60 & 0.58 & 0.25 & 0.30 & 0.31 & 0.30 & 0.78 & 2.00 & 2.41 \\
\hline CD & 6.02 & 1.35 & 5.65 & 4.68 & 1.66 & 0.73 & 0.89 & 0.91 & 0.10 & 2.26 & 5.84 & 7.04 \\
\hline
\end{tabular}


It is evident from the data table 1 and Figure 1 that the maximum number of new sprouts (9.67), number of new leaves (47.00) and survival percentages $(83.00 \%)$ given by IBA@6,000 ppm + Sphagnum moss + Black polythene. The growth parameters of the layers depends on the pre- condition shoots on mother plant, the speed and number of roots formation on layer and post separation environment to which the layer is exposed (Sharma et al., 1975). This might be due to the congenial weather conditions prevailed during these month triggered cell activity resulted in early sprouting, number of sprouts and leaves. Higher accumulation of Carbohydrates and $\mathrm{C}$ : $\mathrm{N}$ ratio, which readily served as a reservoir of food for new growth reflected in layers. Good survival percentage of layers might be attributed favourable external environment factors good sun shine, aeration, optimum temperatures and relative humidity during root initiation, quality of roots, subsequent growth and development of layers.

Transplanted layers having better root system, they could absorb sufficient water and other nutrients from soil and ultimately resulting higher survival percentage. Similar findings were reported by Rymbai and Sathyanarayana Reddy (2010), Kumar and Syamal (2005) and Chandrappa and Gowda (1998) in guava.

\section{References}

Bhagat, B.K.; Jain, B.P.; Singh, C. and Chowdhary, B.M. (1998) Propagation of Guava (Psidium guajava L.) by ground layering. Journal of Research, 10(2): 209-210.

Bhagat, B.K., Jain; B.P., Singh, C. and Chowdhery, B.M. (1999). Studies on the propagation of guava (Psidium guajava L.) by ground layering in poly bages. Orissa J. of Horti. 27(1):19-21
Chandrappa and Gowda, V. N., 1998, Influence of auxin and 1, 2, 3, acid on rooting of guava air layers. Mysore $J$. Agric. Sci., 32: 59-66.

Kumar, K. and Syamal, M. M., 2005, Effect of etiolation and plant growth substances on rooting and survival of air-layers of guava. Indian J. Hort., 62 (3): 290-292.

Maurya, R.K., Ray, N.R., Chavda, J.C., Chauhan V.B. and patil, A.k. (2012). Evaluation of different organic media and water holding materials with IBA on rooting and survival of air layering in guava (Psidium guajava L.) cv. Allahabad safeda, Asian J. Hort. 7(1): 44-47.

Panse, V.G. and Sukhatme, P.V. (1989): Statistical Methods for Agricultural Workers. (Revised by: Sukhatme, P.V. and V.N. Amble) Indian Council for Agricultural Research publication, New Delhi, pp. 100-109.

Patel, R.K., Bose, U.S. and Tripathi, S.K. (1996). Effect of growth regulators and wrappers and success and survival of air- layering in guava cv. Allahabad safeda. Crop Research Hisar. 12(1):5660

Pedapati A and Tiwari RB. 2014. Effect of different Osmotic Pretreatments on Weight Loss, Yield and Moisture Loss in Osmotically Dehydrated, Guava. Journal of Agri Search 1(1):49-54.

Rymbai, H. and Sathyanarayana Reddy, G., 2010, Effect of IBA, time of layering and rooting media on air-layers and plantlets survival under different growing nursery. Indian J. Hort., 67 (4): 99-104.

Sharma, K. K., Sandhu, A. S., Bajwa, M. S. and Dhillon., B. S., 1975, Effect of indole butyric acid and napthalene on the rooting of air-layers of guava (Psidium guajava L.). J. Res. Punjab Agric. Uni, Ludhiana, 12 (1): 23-25. 
Singh, G., 2007, Recent development in Singh, S. and Jawanda, J.S. (1981). production of guava. Acta Hort., 735: 161-176. Propagation studies in litchi Punjab Hort j. (21): 184: 87

\section{How to cite this article:}

Ajay Punasya, Jyoti Kanwar and Rajiv Dubey. 2018. IBA and Rooting Media Influenced Survival, Rooting and Vegetative Growth in Air Layering of Guava (Psidium guajava L.) cv. L-49. Int.J.Curr.Microbiol.App.Sci. 7(08): 1505-1510. doi: https://doi.org/10.20546/ijcmas.2018.708.171 